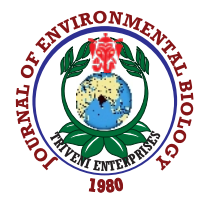

\title{
Establishment of Glyoxalase I gene transformation and regeneration of cotton (Gossypium hirsutum L.)
}

\author{
A. Muthusamy ${ }^{1,2 *}$ \\ ${ }^{1}$ Plant Genetic Manipulation Lab, School of Life Sciences, Jawaharlal Nehru University, New Delhi-110 067, India \\ ${ }^{2}$ Present address: Department of Plant Sciences, Manipal School of Life Sciences, Manipal Academy of Higher Education, Manipal -576 104, India \\ *Corresponding Author Email : amsamy.slsmu@gmail.com
}

\section{Abstract}

Aim: The current study was carried out to develop transgenic cotton plantlets with glyoxalase I (gly /) gene using Agrobacterium-mediated transformation.

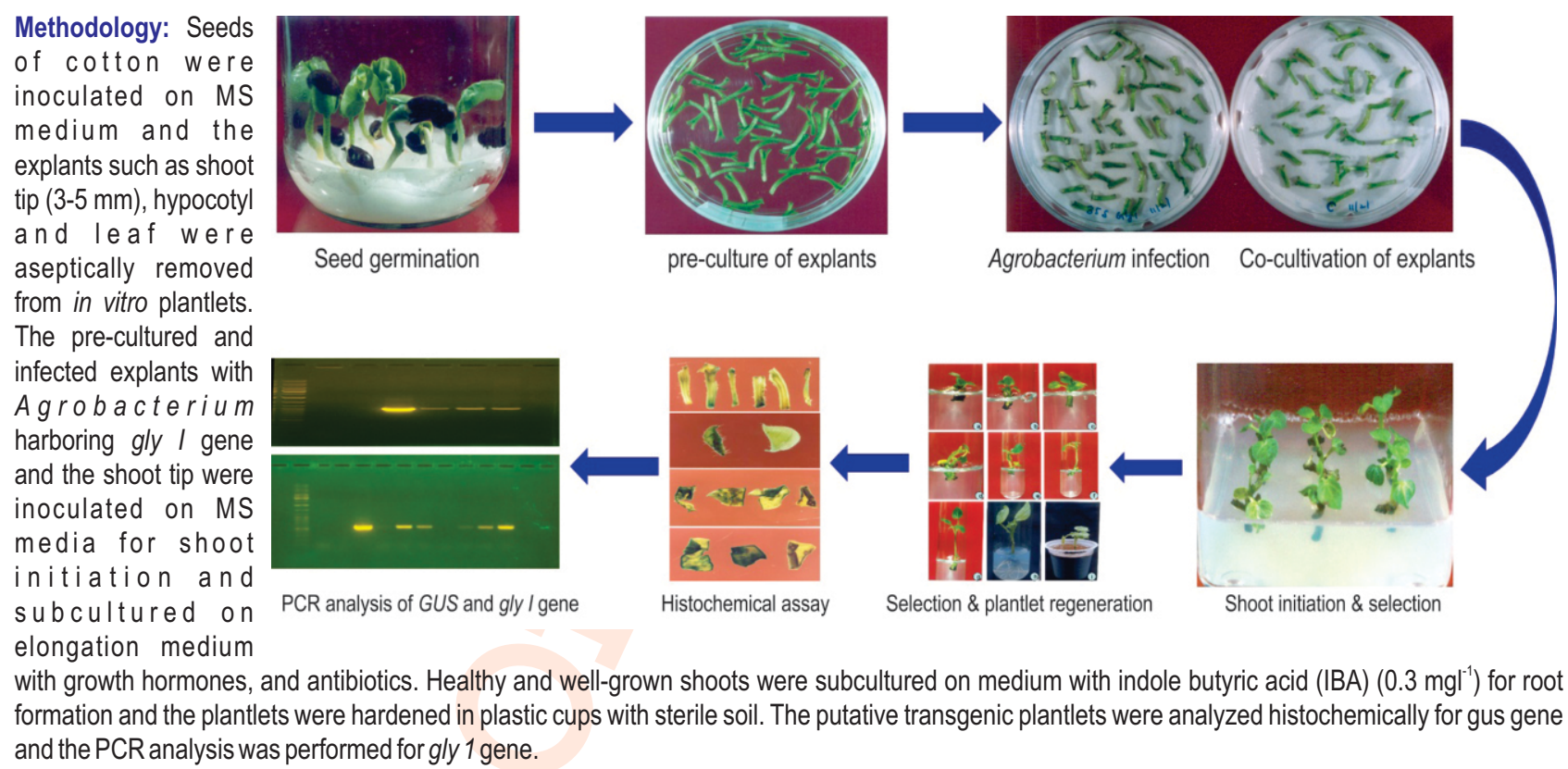

Results: The transformation efficiency of cotton ranged 48.57 to $64.53 \%$. The regenerated plantlets showed the presence of gus gene in terms of blue coloration in shoots, whole leaf and leaf segments. The PCR was performed in putative transgenic plant lets with both gus gene as well as gly I gene primers. The PCR results showed the presence of 1031 bp DNA band with gus gene primers and $800 \mathrm{bp} \mathrm{DNA}$ band with the gly /gene primers.

Interpretation: The current study has proven the reproducible procedure for the Agrobacterium-mediated gene transfer and regeneration of Indian cotton varieties. The PCR results revealed the presence of glyoxalase / gene in the transformants.

Key words: Cotton varieties, Glyoxalase I gene, PCR analysis, Regeneration, Transformation

How to cite : Muthusamy, A.: Establishment of Glyoxalase / gene transformation and regeneration of cotton (Gossypium hirsutum L.). J. Environ. Biol., 42, 203-210 (2021). 


\section{Introduction}

Cotton also known as white gold, is the backbone of world markets and it is deliberated as the highest value-driven industrial cash crop in India, besides being the foremost fiber and oilseed crop in several countries. In native practice and as a commercial product on world market, cotton plays pivotal role as significant source for agricultural industry, which eventually boosts Indian economy. The seeds are the source of cooking oil and the remaining meal with higher amount of essential amino acids used for cattle feed or organic fertilizers. Furthermore, several consumer products are regularly developed as byproducts of cotton industry as additional goods to fiber, which is used extensively in textile industries (Pandey, 1998; Shivagaje et al., 2004).

Several abiotic stresses, such as drought, extreme temperature and nutrient deficiency have potential negative impacts on the vegetative and reproductive growth, which subsequently leads to reduction on agronomical characters of cotton (John, 1997). Due to many incompatibility barriers, it is difficult to exploit the presently available germplasm, though several cotton varieties have been developed for different climatic conditions using conventional methods. Alternatively, the induction of variation and development of plants using plant biotechnological tools such as genetic engineering and molecular breeding has enabled the production of desirable crops for both vegetative as well as reproductive traits, and to cope up with a number of biotic and abiotic stresses (Gasser and Fraley, 1992). Extensive research program has been carried out on cotton germplasms, and subsequently genetic transformation with a variety of potential genes via direct injection of DNA into cotton immature embryos, Agrobacterium-mediated transformation, particle bombardment and combination of Agrobacteriummediated with particle bombardment methods (Zhou et al., 1983; Finer and Mullen, 1990; Rajasekharan et al., 1996; Majeed et al., 2000; Satyavathi et al., 2002; Katageri et al., 2007). Cotton crop is highly sensitive to salt stress leading to drastic decrease in the plant productivity (Bhomkar et al., 2008).

A vast tract of agricultural land in India is presently nonarable due to excessive salinity and an effort to develop salttolerant Gossypium hirsutum is a prime target for ensuring increased productivity (Zhang et al., 2014). Stress response in plants are generally complex and involve expression of many genes. The enzymes glyoxalase I and II are universally present in all organisms and play a vital role in the formation of 2hydroxyacids using gulathione from 2-oxoaldehydes (Thornalley, 1993). Furthermore, overexpression of gly I gene in tobacco results in substantial tolerance of transgenic plants to high salinity and methylglyoxal stress, as related to the untransformed plants (Veena et al., 1999). Higher salt concentrations in soil is one of the utmost severe factors amongst various abiotic stresses, restraining the productivity of agricultural and horticultural crops worldwide. In this context, the development of cotton varieties for improved abiotic stress tolerance, especially for salinity is essential for countries where cotton is cultivated as cash crop,
Therefore, the establishment of efficient and reproducible protocol for developing transgenic cotton plantlets is indispensable. The current study was designed for Agrobacterium-mediated genetic transformation with glyoxalase I (gly I) gene for Indian cotton varieties.

\section{Materials and Methods}

Cotton (Gossypium hirsutum L.) varieties, MCU 5, MCU 12, MCU 13 were acquired from the Department of Plant Breeding and Genetics, Tamil Nadu Agricultural University (TNAU), Coimbatore, Tamil Nadu. The study was performed at Plant Genetic Manipulation Lab, School of Life Sciences, Jawaharlal Nehru University, New Delhi.

Seed germination and culture conditions: Seeds of cotton varieties were treated with Bavistin (5\%) for 20 min and meticulously rinsed with water and surface sterilized using mercuric chloride $(0.1 \% \mathrm{w} / \mathrm{v})$ for $7 \mathrm{~min}$, and washed five times with sterilized water. The seeds were germinated aseptically on semisolid Murashige and Skoog (1962) medium (MS) in culture bottles $(6.5 \times 11 \mathrm{~cm})$ for germination. The shoot apices $(3-5 \mathrm{~mm})$ were removed carefully using sterile scalpel from in-vitro seedlings (5-day old) and inoculated on MS medium augmented with BAP and NAA, phytagel and/or agar. The seeds were maintained at $25 \pm 2^{\circ} \mathrm{C}$ and $16 / 8$-hr photoperiod with $50 \mathrm{\mu E} \mathrm{m}^{-2} \mathrm{~s}^{-1}$ fluorescence intensity.

Direct organogenesis: Soaked seeds and seedlings were used as source of explants such as embryo axes shoot apex, cotyledons and hypocotyls. Based on these primary experiments, the shoot tip explants were selected for further experiments. The shoot explants which responded were subcultured on same medium appended with $\mathrm{GA}_{3}\left(1.0 \mathrm{mg} \mathrm{I^{-1 }}\right)$ for proliferation and growth. Healthy shoot explants $(5-6 \mathrm{~cm})$ were further transplanted to half-strength MS medium fortified with IBA (0.5 $\mathrm{mg}^{-1}$ ) for root initiation.

Vector and bacterial strain: Agrobacterium strain (GV 3101) harboring glyoxalase I gene was used for transformation of explants. The gly / construct was obtained from the International Centre for Generic Engineering and Biotechnology, New Delhi, India. The isolation of plasmid DNA from $E$. coli was performed and the recombinant plasmids with gly I gene were moved into Agrobacterium (GV 3101) (Sambrook et al., 1989). This construct included npt II (neomycin phosphotransferase gene) as plant selectable marker for kanamycin resistance, and gus ( $\beta$ glucuronidase) as reporter gene regulated by $35 \mathrm{~S}$ CaMV promoter.

Transformation and co-cultivation: Agrobacterium strain cultures in MS with BAP $\left(0.1 \mathrm{mg} \mathrm{l}^{-1}\right)+$ acetosyringone $\left(2.0 \mathrm{mg} \mathrm{l}^{-1}\right)$ were taken in $150 \mathrm{ml}$ conical flasks. Pre-cultured shoot tips on liquid MS medium for 2 days were infected with Agrobacterium and incubated in a rotary shaker $(100 \mathrm{rpm})$ at $28^{\circ} \mathrm{C}$ for $20 \mathrm{~min}$. The infected shoot tip explants were transferred to sterile petri plates 
with moist filter paper soaked in BAP $\left(0.1 \mathrm{mgl}^{-1}\right)+$ acetosyringone $\left(2 \mathrm{mgl}^{-1}\right)$ and incubated at $25 \pm 2^{\circ} \mathrm{C}$ for 2 days as co-cultivation period. Uninfected shoot tip explants were processed and maintained as control.

Selection and plant regeneration: The co-cultivated shoot tips were rinsed once with sterile distilled water, followed by washes with cefotaxime $\left(400 \mathrm{mgl}^{-1}\right)$ and then washed with sterile water and subcultured on shoot initiation medium (MS) comprising NAA $\left(0.00,0.10,0.50,1.00 \mathrm{mgl}^{-1}\right)$ and $\operatorname{BAP}\left(0.05,0.10,0.20,0.30 \mathrm{mgl}^{-1}\right)$ respectively in different combinations with kanamycin $\left(75 \mathrm{mgl}^{-1}\right)$ and cefotaxime $\left(200 \mathrm{mg} \mathrm{l}^{-1}\right)$. Proliferation of shoots was achieved with $\operatorname{BAP}\left(0.01 \mathrm{mg} \mathrm{l}^{-1}\right)$, NAA $\left(0.1 \mathrm{mg} \mathrm{l}^{-1}\right)$ and GA3 $\left(1.0 \mathrm{mg} \mathrm{l}^{-1}\right)$ and the elongated shoots were subcultured thrice for selection.

The proliferated shoots on the antibiotic (kanamycin) selection medium were taken to be putative cotton transformants. Kanamycin-resistant, healthy and elongated (< $4 \mathrm{~cm})$ shoots were transferred on medium with IBA $\left(0.3 \mathrm{mgl}^{-1}\right)$, kanamycin $\left(75 \mathrm{mgl}^{-1}\right)$ and cefotaxime $\left(200 \mathrm{mgl}^{-1}\right)$ for root induction. The well-rooted plantlets were hardened in plastic pots using autoclaved vermiculite. Initially, the plantlets were irrigated with tap water and after one week with Hoagland's solution for further growth and development.

Histochemical assay for GUS: $\beta$-glucuronidase activity was accomplished histochemically using putative transgenic and control shoot and leaf tissues (Jefferson et al., 1987). Shoots and leaves from putative transformed and control plantlets were rinsed with water and incubated in GUS staining solution [1 mM sodium phosphate buffer $\mathrm{pH} 7.0$, potassium ferricyanide and ferrocyanide $(0.1 \mathrm{M})$, disodium EDTA $(0.5 \mathrm{M})$ and $\mathrm{X}$-gluc $\left(1.0 \mathrm{mg} \mathrm{l}^{-1}\right)$ ]. After overnight incubation at $37^{\circ} \mathrm{C}$, chlorophyll was removed by immersing the tissues in $70 \%$ ethanol. These were observed and photographed. Transformation efficiency was evaluated as total number of GUS-positive shoots with total number of leaves/ shoot apex.

PCR analysis for gus and gly I gene: DNA was isolated from control and putative transgenic plantlets by CTAB method (Paterson et al., 1993). PCR was performed for uidA (GUS) gene using specific primer sequences (5' - 3') GCC ATT TGA AGC CGA TGT CAC GCC and GTA TCG GTG TGA TGA GCG TCG CAG AAC. PCR was accomplished in $25 \mu$ of reaction mixture comprising of $10 \mu$ reaction buffer, $4.0 \mu$ DNA ( 100 ng), $2.5 \mu \mathrm{l}$ dNTPs, 1.0 $\mu$ l forward and reverse primers, $0.4 \mu \mathrm{l}$ Taq DNA polymerase and autoclaved distilled water. PCR was carried out in a thermal cycler under following conditions: $94^{\circ} \mathrm{C}$ for $5 \mathrm{~min}$ as preheating, $94^{\circ} \mathrm{C}$ for denaturing for $30 \mathrm{sec}, 58^{\circ} \mathrm{C}$ annealing for 30 sec, $72^{\circ} \mathrm{C}$ synthesis for $1 \mathrm{~min}$ and $5 \mathrm{~min}$ at $72^{\circ} \mathrm{C}$ as final extension. Similarly, PCR amplifications of gly I gene was performed using specific primers sequences (5' - 3') CGG GGT ACC ATG GCG TCG GAA GCG AAG and TGC TCT AGA GCT CTC AAG CGT TTCC. PCR was executed in $25 \mu$ l of reaction mixture consisting of $10 \mu$ reaction buffer, 1.0 $\mu$ DNA ( 100 ng), $2.5 \mu \mathrm{l}$ dNTPs, $1.0 \mu \mathrm{l}$ of Gly I primers, $0.4 \mu \mathrm{l}$ Taq DNA polymerase and autoclaved distilled water. PCR was performed in a thermal cycler under following conditions: $94^{\circ} \mathrm{C}$ for $5 \mathrm{~min}$ as preheating, $94^{\circ} \mathrm{C}$ for denaturing for $30 \mathrm{sec}, 56^{\circ} \mathrm{C}$ annealing for $30 \mathrm{sec}, 72^{\circ} \mathrm{C}$ synthesis for $1 \mathrm{~min}$ and $5 \mathrm{~min}$ at $72^{\circ} \mathrm{C}$ as final extension. PCR products of gus and gly / gene were electrophoresed on agarose gel $(1.0 \%)$ and photographed under ultraviolet light.

Statistical Analyses: The experiments were carried out with 25 explants from three varieties in triplicates. The analysis of variance (ANOVA) was performed to calculate mean and standard deviation and related using Duncan's Multiple Range Test for significance (DMRT).

\section{Results and Discussion}

Improvement of cotton crop for fibre, seed oil content, increased gossypol content in vegetative parts and reduction of gossypol content in reproductive parts, abiotic stress tolerance as well as disease resistance are priority areas of research in cotton breeding programs. Induction of genetic variations in cotton using conventional breeding is restricted majorly by dearth of useful variation and time intense process. Currently, genetic engineering is a fascinating technique, which requires effective in-vitro regeneration methods to develop transgenic plants with improved agronomical characters. Effective regeneration protocols have been established for various commercial crops. However, only few regeneration protocols are available for Indian cotton varieties since they are recalcitrant. Although cotton continues to remain a recalcitrant crop, transgenic plants of several cotton varieties have been successfully developed to enhance disease resistance (Perlak et al., 1990) and abiotic stress tolerance (John, 1997; Rajasekharan et al., 1996).

There are very few reports available on the development of transgenic Indian cotton varieties (Kumar et al., 1998; Ganesan et al., 2009; Sumithra et al., 2010a, b; Sangannavar et al., 2011a, b; Sangannavar et al., 2016) for both biotic as well as abiotic stress tolerance. Several factors can have a profound influence on gene transfer of a given plant species using Agrobacterium tumefaciens. Therefore, in this study we have evaluated transformation efficiencies and established gene transfer methods for Indian cotton towards the improvement of abiotic stress tolerance. Amongst different explants, the shoot apex with trimmed cotyledon exhibited maximum response for shoot induction. Subsequently, these shoots were excised and transferred onto $\mathrm{MS}$ medium augmented with $\operatorname{BAP}\left(0.1 \mathrm{mgl}^{-1}\right)$ and NAA $\left(0.1 \mathrm{mgl}^{-1}\right)$ for shoot proliferation.

The growing shoots were subcultured 2-3 times on above mentioned medium where shoot proliferation was achieved. Shoot induction was achieved with differential percentage of responses which ranged between 52.14 and 98.20 with BAP and NAA ( $\left.0.1 \mathrm{mg} \mathrm{l}^{-1}\right)$. Induction of multiple shoots was noted during second subculture with 1-4 multiple shoots. MCU 5 variety showed maximum percentage of shoot initiation amongst the three varieties tested (Table 1 and 2). The shoots were cultured on 
Table 1: Comparison of effect of auxin with cytokinin on percent shoot responses and frequency of shoots per explant in shoot tip culture of cotton varieties

\begin{tabular}{|c|c|c|c|c|}
\hline \multirow[b]{2}{*}{ NAA } & \multicolumn{2}{|c|}{ Hormones (mg l-1) } & \multicolumn{2}{|c|}{ Cotton varieties } \\
\hline & BAP & MCU 5 & MCU 11 & MCU 13 \\
\hline \multirow[t]{4}{*}{0.00} & 0.05 & $52.50(3)^{\mathrm{bc}}$ & $50.17(2)^{d}$ & $53.45(2)^{b c}$ \\
\hline & 0.10 & $54.32(1)^{b}$ & $56.18(1)^{c}$ & $52.56(2)^{c}$ \\
\hline & 0.20 & $64.38(1)^{a}$ & $62.32(2)^{a}$ & $60.23(1)^{a}$ \\
\hline & 0.30 & $52.14(1)^{c}$ & $58.64(1)^{b}$ & $53.58(1)^{b}$ \\
\hline \multirow[t]{4}{*}{0.10} & 0.05 & $73.21(2)^{d}$ & $64.32(2)^{d}$ & $66.48(2)^{c}$ \\
\hline & 0.10 & $98.20(3)^{a}$ & $94.84(2)^{a}$ & $90.26(2)^{a}$ \\
\hline & 0.20 & $84.32(2)^{\text {bc }}$ & $82.17(1)^{b}$ & $85.12(1)^{\mathrm{ab}}$ \\
\hline & 0.30 & $86.60(1)^{b}$ & $80.16(1)^{b c}$ & $79.23(1)^{b}$ \\
\hline \multirow[t]{4}{*}{0.50} & 0.05 & $70.67(2)^{c}$ & $58.17(2)^{d}$ & $63.29(2)^{c}$ \\
\hline & 0.10 & $66.42(2)^{d}$ & $63.17(1)^{c}$ & $68.10(1)^{b}$ \\
\hline & 0.20 & $78.43(1)^{a}$ & $76.80(2)^{a}$ & $82.49(1)^{a}$ \\
\hline & 0.30 & $74.10(1)^{b}$ & $72.17(1)^{\mathrm{ab}}$ & $66.39(1)^{\text {bc }}$ \\
\hline \multirow[t]{4}{*}{1.00} & 0.05 & $82.89(2)^{c}$ & $60.17(2)^{d}$ & $66.28(2)^{\mathrm{cd}}$ \\
\hline & 0.10 & $78.16(2)^{d}$ & $70.16(2)^{c}$ & $69.12(1)^{c}$ \\
\hline & 0.20 & $88.23(1)^{\mathrm{a}}$ & $78.68(1)^{b}$ & $80.20(1)^{a}$ \\
\hline & 0.30 & $86.42(1)^{\mathrm{ab}}$ & $88.28(1)^{\mathrm{a}}$ & $78.56(1)^{\mathrm{ab}}$ \\
\hline
\end{tabular}

The values in parentheses indicate the number of shoots per explants. 1: Single shoot; 2 : two shoots; 3 : three shoots or more per explant. The data on percent shoot responses and frequency of shoots were subjected to ANOVA and mean separation was carried out adopting DMRT. Mean values within a column having the same alphabet are not significantly different $(p=0.05)$ according to DMRT and data are mean of three replicates

Table 2: Comparison of shoot elongation of cotton varieties with $0.1 \mathrm{mgl}^{-1} \mathrm{BAP}$ and NAAand $1.0 \mathrm{mg} \mathrm{l}^{-1} \mathrm{GA}$

\begin{tabular}{llllllll}
\hline Variety & $\begin{array}{l}\text { Number of shoots in } \\
\text { elongation medium }\end{array}$ & $\begin{array}{l}\text { Number of } \\
\text { elongated shoots }\end{array}$ & $\begin{array}{l}\text { Percentage of } \\
\text { shoot elongation }\end{array}$ & $\begin{array}{l}\text { Height of } \\
\text { shoots } \mathbf{( c m})\end{array}$ & $\begin{array}{l}\text { Number of shoots } \\
\text { in rooting medium }\end{array}$ & $\begin{array}{l}\text { Number of } \\
\text { rooted shoots }\end{array}$ & $\begin{array}{l}\text { Percent of } \\
\text { rooting }\end{array}$ \\
\hline MCU 5 & 98.0 & $80.86^{\mathrm{a}}$ & $82.10^{\mathrm{b}}$ & $7.4^{\mathrm{a}}$ & 80.0 & $65.26^{\mathrm{a}}$ & $81.15^{\mathrm{a}}$ \\
MCU 12 & 96.0 & $79.64^{\mathrm{ab}}$ & $82.77^{\mathrm{ab}}$ & $6.9^{\mathrm{bc}}$ & 74.0 & $55.78^{\mathrm{b}}$ & $75.37^{\mathrm{b}}$ \\
MCU 13 & 94.0 & $78.46^{\mathrm{b}}$ & $83.46^{\mathrm{a}}$ & $7.0^{\mathrm{b}}$ & 70.0 & $50.46^{\mathrm{c}}$ & $72.08^{\mathrm{c}}$ \\
\hline
\end{tabular}

Data on number of elongated shoots, percentage of shoot elongation and height shoots were subjected to ANOVA and mean separation was carried out adopting DMRT. Mean values within a column having same alphabet are not significantly different $(p=0.05)$ according to DMRT and data are mean of three replicates

Table 3: Transformation efficiency of Indian cotton varieties

\begin{tabular}{lllll}
\hline Varieties & Sample & Number of explants & Shoots on selection medium & Transformation efficiency (\%) \\
\hline MCU 5 & I) Control & 50 & 0 & 00.00 \\
\multirow{2}{*}{ MCU 11} & ii) Transformed & 815 & 526 & 64.53 \\
& I) Control & 50 & 0 & 00.00 \\
MCU 13 & ii) Transformed & 725 & 409 & 56.41 \\
& I) Control & 50 & 0 & 00.00 \\
& ii) Transformed & 735 & 357 & 48.57 \\
\hline
\end{tabular}

${ }^{a}$ Expressed as number of explants surviving on $75 \mathrm{mg} \mathrm{I}^{-1}$ kanamycin in the medium

MS medium with activated charcoal $(0.1 \%)$ for two weeks and later the shoots were transferred on charcoal free MS medium augmented with BAP, NAA $\left(0.1 \mathrm{mg} \mathrm{l}^{-1}\right)$ and $\mathrm{GA}_{3}\left(1.0 \mathrm{mg} \mathrm{l}^{-1}\right)$ for multiplication and shoot elongation. The responded shoots were cultured for further multiplication, after 2-3 passage of subculture, the multiple shoots were transplanted on medium appended with $\mathrm{GA}_{3}\left(1.0 \mathrm{mgl}^{-1}\right)$ for shoot elongation. Elongated shoots $(<4 \mathrm{~cm})$ were subcultured for root initiation onto medium augmented with IBA $\left(0.3 \mathrm{mgl}^{-1}\right)$. Number of shoot elongation ranged from 82.1 to $83.46 \%$ in MS medium with charcoal for 2 weeks and alternate 
with charcoal free MS medium with hormones (Table 2). Amongst several combinations of cytokinins and auxin (Table 1) tested for direct organogenesis, $0.1 \mathrm{mg} \mathrm{l}^{-1} \mathrm{NAA}$ and BAP showed highest responses in shoot initiation, followed by BAP and NAA $(2.0+1.0$ $\left.\mathrm{mgl}^{-1}\right)$, BAP and NAA $\left(2.0+0.5 \mathrm{mg} \mathrm{l}^{-1}\right)$ and BAP $\left(0.2 \mathrm{mg} \mathrm{l}^{-1}\right)$. The NAA and BAP combinations resulted in shoot initiation in all varieties and the response was higher in MCU 5 than other varieties (Table 1,2). Comparable results were described earlier by shoot tip culture and development of plantlets (Gould et al., 1991; Hemphill et al., 1998; Zapata et al., 1999) with lower percentages, whereas by Satyavathi et al. (2002) and Muthusamy et al. (2004) and Khatoon et al. (2014) described higher percentage of plantlet regeneration. Plantlets with wellestablished roots were transplanted in plastic cups with autoclaved soil for hardening.

Fortification of $\mathrm{GA}_{3}\left(1.0 \mathrm{mg} \mathrm{l}^{-1}\right)$ along with BAP and NAA $\left(0.1 \mathrm{mg} \mathrm{I}^{-1}\right)$ showed marginal proliferation in number of shoots and shoot elongation. Higher proportion of shoot elongation was observed in MCU 5 and the shoot height increased to $7.4 \mathrm{~cm}$ (Table 3). The responses of shoot initiation, elongation and rooting in all eight different genotypes were significant according to DMRT. The developmental stages of transgenic plantlets of MCU 5 were observed with reference to the control. Although the explants remained green during in-vitro culture, some of the shoots showed $10-15 \mathrm{~mm}$. Putative transgenic shoots were transplanted on MS $\left(1 / 2\right.$ strength) with IBA $\left(0.3 \mathrm{mg} \mathrm{l}^{-1}\right)$ for root initiation. Root initiation was noted in 15-20 days of subculture and percentage of rooting differed with different genotypes (Table 2).

The range of transformation efficiency from 48.57 to $64.53 \%$ was observed in MCU varieties. Well-rooted putative transgenic and control plants were hardened in plastic cups and molecular analysis was carried out for gus and gly I gene expression. The shoots, whole leaf or segments from T0 transgenic as well as control plants were stained in X-glue for histochemical GUS assay. The GUS expression was detected in shoots (Fig. 1a), whole leaf (Fig. 1b) and leaf segments (Fig. 1c-d) of putative transgenic lines whereas no GUS activity was noted in shoots, leaf and segments from control plants. Similar gus positive transgenic lines was reported using gly I gene in Vigna mungo (Bhomkar et al., 2008). Further, PCR analysis was performed with shoots, which showed kanamycin resistance for PCR analysis of transgenic lines. Majority of the shoots from TO plantlets exhibited amplification of $1031 \mathrm{~kb}$ fragment of the gus gene (Fig. 2a) and $800 \mathrm{~kb}$ fragment of the gly / gene (Fig. 2b). No PCR amplification was observed in untransformed controls plantlets.

The shoot growth of cotton varieties on selection medium showed differential transformation frequencies with in the range of $48.57-64.53 \%$. Our results are in conformity with $60-70 \%$ transformation efficiency in cotton (Satyavathi et al., 2002). Further, the present observations corroborates with genetic transformation of cotton by Banerjee et al. (2002), Katageri et al. 2007, Ganesan et al. (2009), Sangannavar et al.
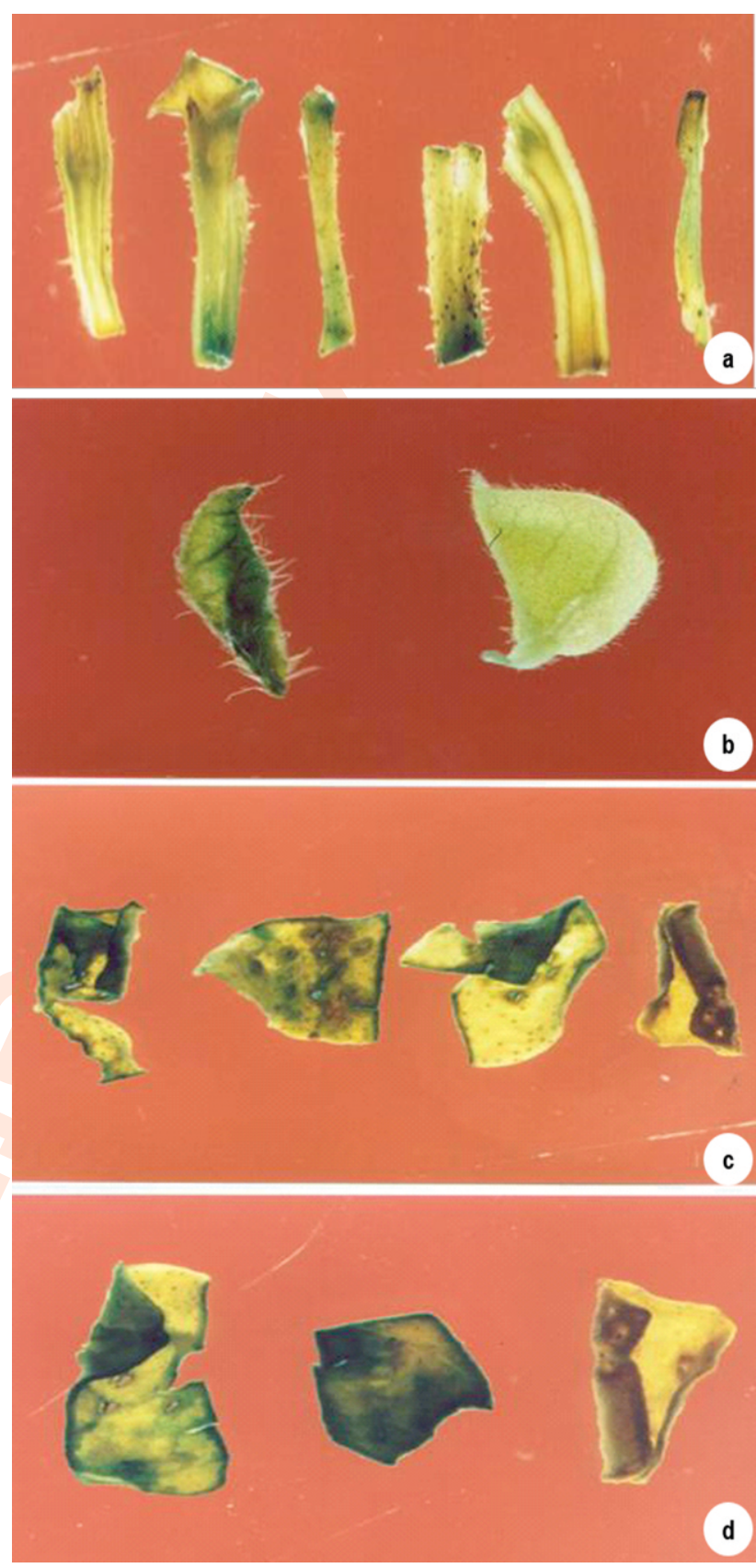

Fig. 2: Histochemical detection of GUS gene expression in shoots, whole leaf and segments: (a) control (left) and transformed shoots (right); (b) whole leaf transformed (left) and control (right); (c-d) Leaf segments showing characteristic blue coloration (left) when incubated overnight in Gus buffer at $37^{\circ} \mathrm{C}$. No GUS activity seen in untransformed (control, right) tissues.

(2011a, b; 2016). In contrast, 6.5 and $9.6 \%$ of transformation efficiency was reported in cotton (Finer and McMullen, 1990; Majeed et al., 2000) and 12\% of Gly I gene transformation efficiency was reported in Vigna mungo (Bhomkar et al., 2008). The shoots and leaf from putative transgenic plantlets were 

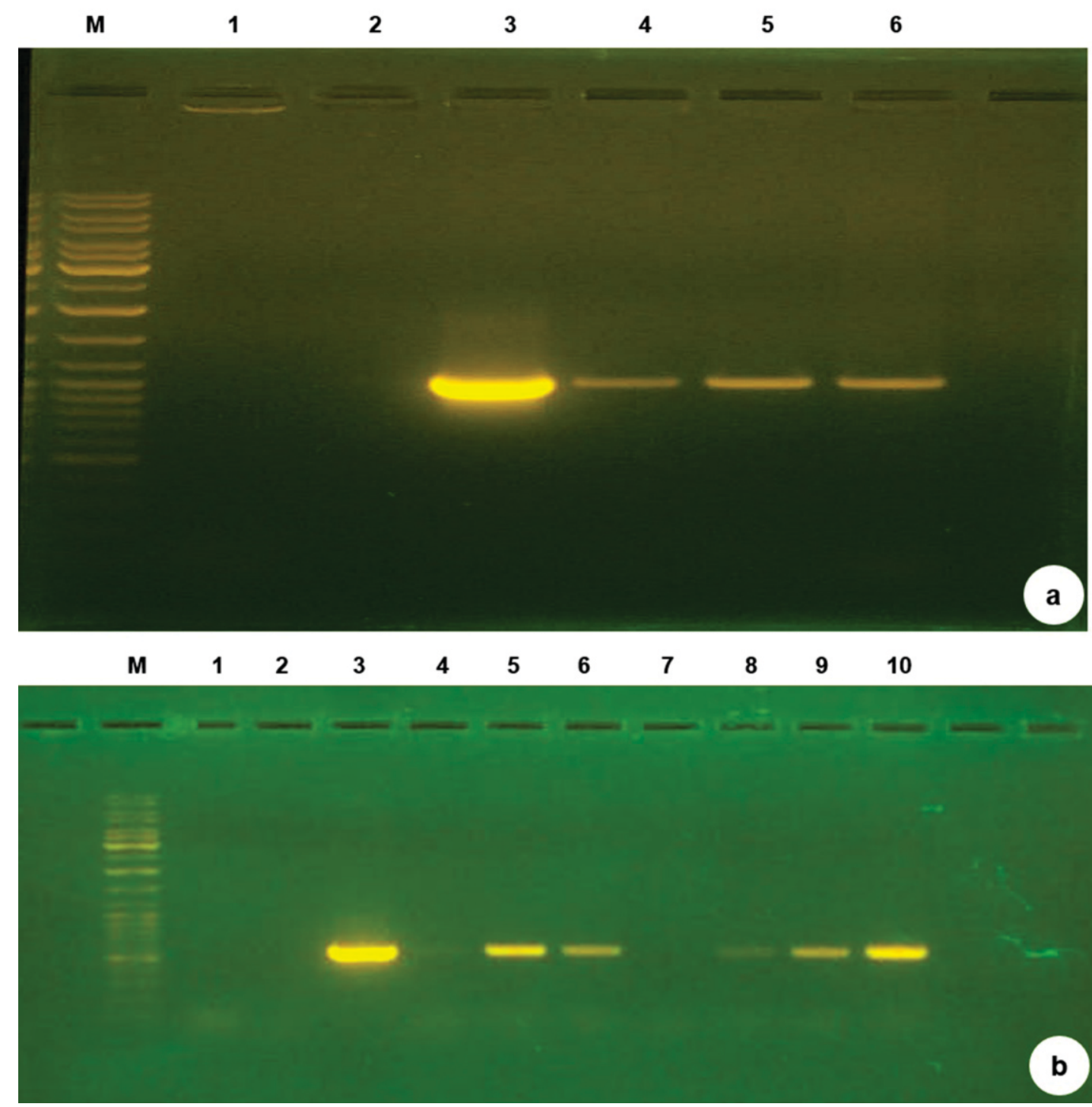

Fig. 2: PCR analysis of T0 transgenic lines of cotton with GUS gene specific primers; (a). Lane M: molecular size marker; lane 1: untransformed control; lane 2: negative control; lane 3: positive control (DNA from plasmid pBI-S2); lane 4-6 putative transgenic cotton and PCR analysis of T0 transgenic lines of cotton with Gly / gene specific primers; (b) Lane M: DNA ladder, lane 1: untransformed control; lane 2: negative control; lane 3: positive control (DNA from plasmid pBI-S2); lane 4-10 putative transgenic cotton plantlets.

positive whereas tissues form untransformed control showed negative for GUS and Gly I gene. The GUS positive putative transgenic plantlets were maintained, PCR was done for the occurrence of gly I gene and the selected putative transgenic lines showed affirmative for $0.8 \mathrm{~kb}$ Gly / gene.

The PCR results revealed the presence of gly / gene in transgenic lines. Further experiments will be required for the confirmation of integration of gene using Southern blots and RTPCR, southern and northern analysis, physiological analysis and tolerance test with transgenics of cotton. Similarly, Ganesan et al.
(2009) reported the development of Indian cotton with rice Chitinase gene (Chi II) for fungal resistance. Recently, Siddiqui et al. (2019) reported double transgenic cotton with Cry1Ac and Cry2Ab for durable resistance against bollworms. In conclusion, the effort was made in the study to transfer the gly I gene into Indian cotton varieties via Agrobacterium-mediated transformation.

The present study proved the possibility to transform novel Indian cotton varieties and regeneration of plantlets, and successful standardization of protocol for development of transgenic cotton with gly / gene for abiotic stress tolerance. 


\section{Acknowledgments}

The author is very grateful to Prof. Neera Bhalla Sarin, former Professor \& Dean, School of Life Sciences, Jawaharlal Nehru University, New Delhi for her constant guidance, suggestion and encouragement and Prof. S.K. Sopory, I.C.G.E.B. New Delhi, India for generous gift of the gly I gene construct. The financial assistance from Council of Scientific and Industrial Research (CSIR), Govt. of India in the form of Research Associateship (Ref.No.9/263 (513)/2004-EMR-I) is gratefully acknowledged. Author would like to express sincere gratitude to Dr. Mukesh Saxena, Dr. Mohd. Aslam Yusuf, Dr. Chandrama Upadhyay, and Dr. Deepak Kumar for their experimental assistance.

\section{Add-on Information}

Author' contribution: A. Muthusamy: Plan of the study, experiments, data analysis, preparation of tables and figures, preparation and revision of manuscript.

Research content: The research content is original and has not been published elsewhere

\section{Ethical approval: NotApplicable}

Conflict of interest: The author declare that there is no conflict of interest.

\section{Data from other sources: NotApplicable}

Consent to publish: Author agree to publish the paper in Journal of Environmental Biology.

\section{References}

Ball, R.A., D.M. Oosterhuis and A. Mauromoustakos: Growth dynamics of the cotton plant during water-deficit stress. Agronomy J., 86, 788-795 (1994).

Bannerjee, A.K., D.C. Agrawal, S.M. Nalawade and K.V. Krishnamurthy: Transient expression of $\beta$-glucuronidase in embryo axes of cotton by Agrobacterium and particle bombardment methods. Biol. Plant, 45, 359-365 (2002).

Bayley, C., N. Trolinder, C. Ray, M. Morgan, J.E. Quinsenberry and D.W. Ow: Engineering 2,4-D resistance into cotton. Theor. Appl. Genet., 83, 645-662 (1992).

Bhomkar, P., C.P. Upadhyay, M. Saxena, A. Muthusamy, N. Shiva Prakash, M. Poggin, R. Hohn and N.B. Sarin: Salt stress alleviation in transgenic Vigna mungo L. Hepper (blackgram) by overexpression of the glyoxalase I gene using a novel Cestrum yellow leaf curling virus (CmYLCV) promoter. Mol. Breed., 22, 169181 (2008).

Deswal, R., T.N., Chakravarty and S.K. Sopory: The glyoxalase system in higher plants: Regulation in growth and differentiation. Biochem. Soc. Trans., 21, 527-530 (1993).

Finer J and M. Mc Mullen: Transformation of cotton (Gossypium hirsutum L.) via particle bombardment. Plant Cell Rep., 8, 586-589 (1990).

Ganesan, M., P. Bhanumathi, K. Ganesh Kumari, A. Lakshmi Prabha, Pill-Soon Song and N. Jayabalan: Transgenic Indian cotton
(Gossypium hirsutum) harboring rice chitinase gene (Chi II) confers resistance to two fungal pathogens. Am. J. Biochem. Biotechnol., 5, 63-74 (2009).

Gasser, C.S and R.T. Fraley: Transgenic crops. Sci. Am., 266, 62-69 (1992).

Gould, J., S. Banister, O. Hasegawa, M. Fahima and R. Smith: Regeneration of Gossypium hirsutum and G. barbadense from shoot apex tissue for transformation. Plant Cell Rep., 10, 12-16 (1991).

Hemphill, J.K., C.G.A. Maier and K.D. Chapman: Rapid in-vitro plant regeneration of cotton (Gossypium hirsutum L.). Plant Cell Rep., 17, 273-278(1998).

Jefferson, R.A., T.A. Kavanagh and M. Bevan: GUS fusions: Betaglucuronidase as a sensitive and versatile gene fusion marker in higher plants. EMBO J., 6, 3901-3907 (1987).

John, M.E.: Cotton crop improvement through genetic engineering. Crit. Rev. Biotechnol., 17, 185-208 (1997).

Katageri, I.S., H.M. Vamadevaiah, S.S. Udikeri, B.M. Khadi and P.A. Kumar: Genetic transformation of an elite Indian genotype of cotton (Gossypium hirsutum L.) for insect resistance. Curr. Sci., 93, 1843-1847 (2007).

Keshamma, E., S. Rohini, K.S. Rao, B. Madhusudhan and M. Udayakumar: Tissue culture independent in planta transformation strategy: An Agrobacterium tumefaciens mediated gene transfer method to overcome recalcitrance in cotton (Gossypium hirsutum). J. Cotton Sci., 12, 264-272.

Khatoon, S., M. Akmal N.B. Sarin and J.A. Khan: Cytokinins improve shoot regeneration efficiency in two Indian cotton (Gossypium hirsutum cv. Narashima and G. arboreum cv. AKA-7) cultivars. Adv. App. Agric. Sci., 2, 25-31 (2014).

Kumar, S., P. Sharma and D. Pental: A genetic approach to in-vitro regeneration of non-regenerating cotton (Gossypium hirsutum L.) cultivars. Plant Cell Rep., 18, 59-63 (1998).

Lyon, B.R., Y. Cousins, D.J. Llewellyn and E.S. Dennis: Cotton plants transformed with a bacterial degradation gene are protected from accidental spray drift damage by the herbicide 2,4dichlorophenoxyacetic acid. Transgenic Res., 2, 162-169 (1993).

Majeed, A., T. Husnain and S. Riazuddin: Transformation of virus resistant genotype of Gossypium hirsutum L. with pesticidal gene. Plant Biotech., 17, 105-110 (2000).

Malik, R.S., J.S. Dhanka and N.C. Turner: Influence of soil water deficits on root growth of cotton seedlings. Plant Soil, 53, 109-105 (1979).

Murashige, T. and F. Skoog: A revised medium for rapid growth and bioassay with tobacco tissue cultures. Physiol. Plant., 15, 473-497 (2006).

Muthusamy, A., K. Vasanth and N. Jayabalan: In-vitro regeneration of cotton plants from shoot tip explants - A simple and alternative method. Plant Cell Biotech. Mol. Biol., 5, 15-20 (2004).

Pandey, S.N.: Cottonseed and its utilization. Indian Council of Agricultural Research, New Delhi, India (1998)

Paterson, A.H., C.L. Brubaker and J.F. Wendel: A rapid method for extraction of cotton (Gossypium spp.) genomic DNA suitable for RFLP or PCR analysis. Plant Mol. Biol. Rep., 11, 122-127 (1993).

Perlak, F.J., R.W. Deaton, T.A. Armstrong, R.L. Fuchs, S.R. Sims, J.T. Greenplate and D.A. Fischhoff: Insect resistant cotton plants. Biotechnology, 8, 939-943 (1990).

Rajasekharan, K., J.W. Grula, R.L. Hudspeth, S. Pofelis and D.M. Anderson: Herbicide resistance Acala and Coker cottons transformed with a native gene encoding mutant forms of acetohydroxyacid synthase. Mol. Breed., 2, 307-319 (1996).

Ramaswamy, O., S. Guha-Mukherjee and S.K. Sopory: Presence of glyoxalase 1 in pea. Biochem. Int., 7, 307-318(1983) 
Ramaswamy. O., S. Guha-Mukherjee and S.K. Sopory: Correlation of glyoxalase 1 activity with cell proliferation in Datura callus culture. Plant Cell Rep., 3, 121-124 (1984).

Sambrook, J., E.F. Fritschi and T. Maniatis: Molecular cloning: A laboratory manual. Cold Spring Harbor Laboratory Press, New York (1989).

Sangannavar, P.A., I.S. Katageri, M.P. Jadhav and H.M. Vamadevaiah: In planta genetic transformation in cotton (G. hirsutum L.). J. Farm Sci., 29, 318-321 (2016).

Sangannavar, P., I.S. Katageri, H.M. Vamadevaiah, N. Chikodi, B.M. Khadi and P. A. Kumar: Genetic transformation studies in cotton: a) Effect of pre-culture, colonization, co-cultivation and vacuum infiltration on regeneration of explants b) Effect of trimming, chilling injury, sand injury and blot drying on regeneration of explants. Cotton Res. J., 2, 21-32 (2011a)

Sangannavar, P., I.S. Katageri, H.M. Vamadevaiah and B.M. Khadi: Effect of external damage on regeneration of cotton explants (Gossypium arboreum and G. barbadense), Karnataka. J. Agric. Sci., 24, 629-632 (2011b)

Satyavathi, V.V., V. Prasad, B. Gita Lakshmi and G. Lakshmi Sita: High efficiency transformation protocol for three Indian cotton varieties via Agrobacterium tumefaciens. Plant Sci., 162, 215-223 (2002).

Seraj, Z.I., A.B. Sarker and A.S. Islam: Plant regeneration in a jute species (C. capsularis) and its possible relationship with glyoxalase-1. Plant Cell Rep., 1, 29-33 (1992).

Sethi, U., A. Basu and S. Guha-Mukherjee: Control of cell proliferation and differentiation by regulating polyamine biosynthesis in cultures of Brassica and its correlation with glyoxalase 1 activity. Plant Sci., 56, 167-175(1988).

Shivagaje, A., M. Kasture, D. Yadav, N. Pandharikar and M. Mathankar: Cotton scenario in India. Curr. Sci., 87, 8 (2004).

Siddiqui, H.A., M. Asif, S. Asad, R.Z. Naqvi, Sobia Ajaz, N. Umer, N.
Anjum, I. Rauf, M. Sarwar, M. Arshad, I. Amin, Muhammad Saeed, Z. Mukhtar, A. Bashir and S. Mansoor: Development and evaluation of double gene transgenic cotton lines expressing Cry toxins for protection against chewing insect pests. Sci. Rep., $\mathbf{9}$, 11774 (2019).

Sumithra, S., I.S. Katageri and H.M. Vamadevaiah: Factors influencing regeneration and Agrobacterium mediated transformation of Gossypium herbaceaum and Gossypium hirsutum cotton genotypes. Karnataka J. Agric. Sci., 23, 222-226 (2010a).

Sumithra, S., H.M., Vamadevaiah, Savith G. Kanthi and I.S. Katageri: Effect of wounding methods on regeneration and transformation in Gossypium herbaceum and Gossypium hirsutum cotton genotypes. J. Cotton Res. Develop., 24, 164-173 (2010b).

Thomas, J.C., D.G. Adams, V.D. Keppenne, C.C. Wasmann, J.K. Brown, M.R. Kanost and H.J. Bohnert: Protease inhibitors of Maduca sexta expressed in transgenic cotton. Plant Cell Rep., 14, 758-762 (1995).

Thornalley, P.J.: The glyoxalase system in health and disease. Mol. Aspects Med., 14, 287-371 (1993).

Veena, V.S. Reddy and S.K. Sopory: Glyoxalase from Brassica juncea: Molelcular cloning, regulation and its over-expression confer tolerance in transgenic tobacco under stress. Plant J., 17, 385-395 (1999)

Zapata, C., S.H. El-Zik, K.M. Park and R.H. Smith: Transformation of a Texas cotton cultivar by using Agrobacterum and shoot apex. Theor. Appl. Genet., 98, 252-256 (1999).

Zhang, L., H. Ma, T. Chen, J. Pen, S. Yu and X. Zhao: Morphological and physiological responses of cotton (Gossypium hirsutum L.) plants to salinity. PLOS ONE, 9, e112807 (2014).

Zhou, G.Y., J. Weng, Y. Zeng, J. Huang, S. Qian and G. Liu: Introduction of exogenous DNA into cotton embryos. Methods Enzymol., 101, 433-481 (1983). 